\title{
Article
}

\section{Polish Culture in the Face of the COVID-19 Pandemic Crisis}

\author{
Angelika Kantor ${ }^{1}$ iD and Jakub Kubiczek ${ }^{2, *(D)}$ \\ 1 Department of Consumer Research, University of Economics in Katowice, ul. 1 Maja 50, \\ 40-287 Katowice, Poland; angelika.kantor@edu.uekat.pl \\ 2 Department of Economic and Financial Analysis, University of Economics in Katowice, ul. 1 Maja 50, \\ 40-287 Katowice, Poland \\ * Correspondence: jakub.kubiczek@edu.uekat.pl; Tel.: +48-607-162-731
}

Citation: Kantor, Angelika, and Jakub Kubiczek. 2021. Polish Culture in the Face of the COVID-19 Pandemic Crisis. Journal of Risk and Financial Management 14: 181. https://doi.org/10.3390/jrfm14040181

Academic Editor: Irena Jindřichovská

Received: 22 February 2021

Accepted: 7 April 2021

Published: 14 April 2021

Publisher's Note: MDPI stays neutral with regard to jurisdictional claims in published maps and institutional affiliations.

Copyright: (c) 2021 by the authors. Licensee MDPI, Basel, Switzerland. This article is an open access article distributed under the terms and conditions of the Creative Commons Attribution (CC BY) license (https:// creativecommons.org/licenses/by/ $4.0 /)$.

\begin{abstract}
Cancellation of the events offered by cultural institutions was caused by the restrictions introduced by the government and, at a critical moment, a national lockdown. The COVID-19 pandemic forced cultural institutions to adapt to the new reality. The aim of this article was to present the impact of the pandemic on the activities of cultural institutions, as well as to identify and systematize the activities of such institutions during the pandemic. The following classification, dividing the activities into three groups, has been proposed: virtualization of existing activities, expansion of activities with additional initiatives, and implementation of corporate social responsibility (CSR) initiatives. The greatest challenge was the virtualization of the existing activities and finding new customer markets. The pandemic has contributed to a significant deterioration in the financial situation of cultural institutions because of the reduced income. Long-term effects on cultural institutions may be difficult to predict and losses may be difficult to rebuild.
\end{abstract}

Keywords: culture; COVID-19 pandemic; virtualization of culture; cultural institutions; corporate social responsibility

\section{Introduction}

Due to the growing number of COVID-19 cases at the beginning of 2020, many sectors of the economy faced significant restrictions. The difficult situation can be observed in almost all areas of the economy. The activities of enterprises were limited and some of them lost financial liquidity, thus finding themselves in a difficult financial situation. Organizations around the world have felt the effects of the spread of the coronavirus (Donthu and Gustafsson 2020). They were associated with each sector of the economy. Transport and trade between countries has been restricted (McKibbin and Fernando 2020). As a result, this led to an economic slowdown that affected the behavior of entrepreneurs and consumers (Zwanka and Buff 2020). The changes also affected the creative sector. They concerned the suspension of activities and the need to change the way of operation. In order to limit the spread of coronavirus, many economic entities have been suspended. The vision of a company's bankruptcy leads to a decision to minimize costs, and this translates into reduced employment. Such actions may have a negative impact on the economy (Wnukowski 2020). Decisions restricting economic activity should be taken with great accuracy and caution in order to prevent an economic collapse not only in the country, but also around the world (Spanulescu and Gheorghiu 2020, pp. 7-19).

For an entire country, implemented restrictions are a significant macroeconomic problem. Ensuring the stability of the economy in time of the pandemic has become a priority for the government. In order to stop the wave of bankruptcies, various aid programs were implemented. In the cultural sector, the government implemented Culture Support Fund to support institutions facing the economic effects of COVID-19 pandemic. Similar initiatives have been implemented by local government units. The positive social impact of culture on society is noticed not only by the state but also by local governments 
and individuals who also have undertaken actions to provide aid to the cultural sector during this difficult time.

The outbreak of the coronavirus pandemic has created many areas of research. In economic sciences, it is important to determine the impact of the pandemic and the introduced restrictions concerning the activities of economic agents. It is particularly interesting to learn about the course of adjustment processes in services and culture, as this is the area particularly affected by the pandemic. Therefore, this article is a part of the identified research gap-the adaptation of cultural institutions to the prevailing conditions during the first wave of the pandemic.

The aim of this study is to present the impact of the pandemic on the activities of cultural entities as a specific economic sector. Additionally, the study identifies and systematizes the activities of cultural institutions in the pandemic, indicating their common features and socially responsible initiatives undertaken by them. In connection with the adopted goal, the following research questions were asked:

- How did the pandemic affect the cultural activities in Poland?

- What are the similarities in the activities of cultural institutions?

- To what extent have cultural institutions been involved in socially responsible initiatives?

The article is structured as follows. Section 2 presents an overview of the role of culture as an important economy sector, the essence of CSR in the activities of cultural institutions and the impact of the pandemic on these institutions. Section 3 and 4 involves the way the pandemic affected the cultural activities in Poland, as well as an attempt to systematize these activities in the era of the coronavirus pandemic. Section 5 is a discussion of how Polish culture handles the activity aspect in the pandemic. Section 6 is a summary of the paper.

\section{Literature Review}

The concept of culture is ambiguous and difficult to classify (Włodarczyk 2003). Depending on the teachings, one may encounter different perceptions of this concept. It can be assumed that culture includes patterns, values and social norms that dominate in a given community (Kostro 2009, p. 34). Thus, culture connects intangible and tangible goods that are human achievements. According to Geertz (2003), culture encompasses every sphere of human life, including cultural institutions and interpersonal relations. Through culture, people pass certain patterns, social practices and beliefs, creating a spiritual space for life, from generation to generation (Kroeber 1987).

The role of culture is a significant element of the national economy. The impact of cultural sectors on cities (Bailey Christopher and Stark 2004) and villages (White 2010) is investigated. It was found that the development of culture may favor employment, the creation of new jobs, and thus fight against unemployment (Abisuga Oyekunle and Sirayi 2018). According to Campbell et al. (1976), the quality of life is influenced by family and professional life, neighborly relations, social relations, health, leisure activities, housing and financial conditions, education, and standard of living. Many of these elements are significantly influenced by culture. In the past year, the state of people's mental health is deteriorating, which is confirmed by the growing number of suicides (Nguyen et al. 2020). Lack of entertainment and interpersonal contacts negatively affects society. Thanks to theaters, cinemas, and concerts, it is possible to maintain mental health, actively spend time, and maintain social relations. All of these are necessary to achieve satisfaction and a high standard of living. The development and continued functioning of cultural entities is particularly important during a pandemic.

Nowadays, when talking about culture, it is necessary to emphasize the concept of economic culture which creates patterns and attitudes related to economic life. It is believed that culture is directly related to economic development (Grabowska-Pieśla 2013). Its impact is considered in terms of cultural features and macroeconomic factors (Kowalczyk 2012, pp. 6-7). However, this impact depends on random events and is 
determined by conditions such as wars or natural disasters. In order to be able to analyze economic culture, it should be emphasized that it includes social and human capital (Gardocka 2005, p. 232). Social capital could be understood as the way of organizing socioeconomic life, mutual networks of connections between individuals and relationships, while human capital is understood as knowledge, skills and the tendency to risk.

The concept of culture is equated with economic development (Weber 1994). Nevertheless, for cultural institutions, in order to be able to operate dynamically and contribute to the formation of the creative sector, it is not only to possess knowledge about modern technology, but to possess the technology itself (Kubicka 2016). By using the available resources and tools, cultural institutions increase their competitiveness, reach a larger number of recipients and increase user satisfaction (Gaanguly Anirban and Chatterjee 2019). The cultural industry is also important in the development of cities, as it allows to brighten the image of a given place and raise its value (Środa-Murawska and Szymańska 2013).

Culture and economy interact with each other. The phenomenon of the economization of culture and the culture of the economy is presented in Figure 1.

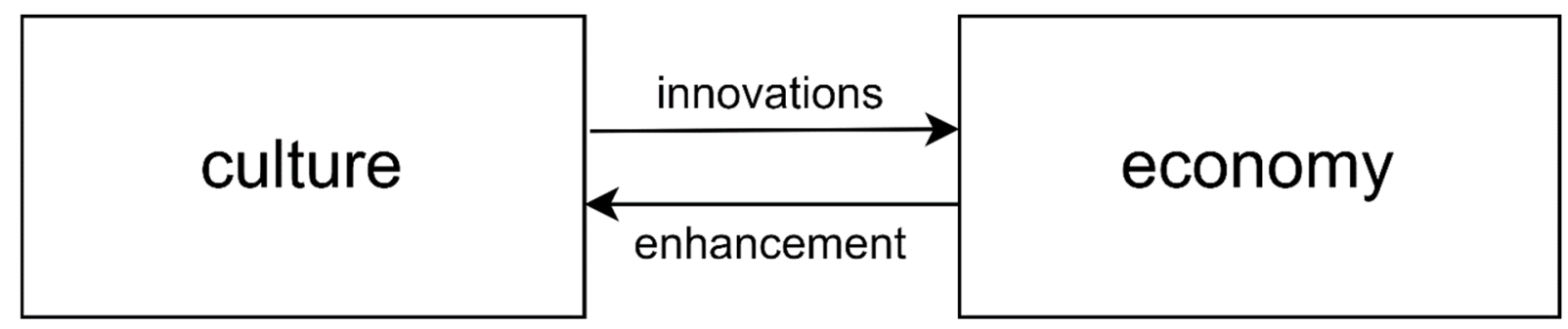

Figure 1. The relationship between culture and economy. Source: own study based on (Klasik 2010, p. 7).

There is a continuous relationship between culture and economy. Culture is a source of innovation, creativity, prosperity and social values, but, it would not exist without the influence of the economy that drives the actions (Klasik 2010).

Culture stimulates the development of creative industries (Kwiecień 2020, p. 11). Nowadays, this concept includes creative professions and sectors of the economy (DCMS 2011). The creative industry can also be classified on the basis of its characteristics. The next step is to asset the behavior and projects of an organization (Caves 2000).

The development of culture impacts society and the overall satisfaction of the population. Culture contributes to the improvement of the quality of life (Wilkin 2016) because it creates a friendly place for intellectual development and recreation. Additionally, it creates jobs. The creative sector has a direct impact on the public mood and the development of society. According to the theory of creative capital, people-friendly places create better conditions for business growth (Żak 2020, pp. 18-19). Culture is aimed at people, it creates a diverse, common space that is available to everyone.

Culture has a direct impact on society and social mood. It should be emphasized that people as social creatures are negatively affected by the effects of the pandemic, which is exacerbated by isolation (Cacioppo and Hawkley 2009). The feeling of being in danger contributes to cognitive dysfunction and mental illnesses. In order to positively influence the behavior of the population, it is necessary to provide entertainment that allows to forget about everyday problems. This is especially important during a pandemic. Participation in cultural events helps to maintain mental health.

\subsection{Corporate Social Responsibility and Cultural Institutions}

Culture should create appropriate conditions for growth. It should integrate society and generate innovation. To make this possible, its economic rationale and social consequences should be understood (Lee 2017a). Culture contributes to an increase in the quality of life and diversity. This allows to generate innovative ideas and create new solutions. Diversity and quality of life are elements that are of great importance for society in the 21st 
century. Companies, non-governmental organizations and cultural institutions implement the concepts of corporate social responsibility

(CSR) in order to respond to social problems and gain the favor of consumers (Park et al. 2017). CSR can be defined as the responsibility of an organization for its activities and its negative impact on society (ISO 26000 2012). In the long term, this concept contributes to the creation of benefits for organizations, customers and the environment. Thanks to this, it is possible to create a high quality of life for society. By focusing on achieving socio-economic benefits, it is possible to build a positive image of the region and improve the quality of life (Kantor and Kubiczek 2020, p. 45).

To make this possible, it is necessary to support cultural units that are directly related to the concept of CSR. Theaters and museums are very often beneficiaries of socially responsible initiatives. At the same time, they contribute to socially responsible activities by contributing to the education and development of people at risk of social exclusion. The cultural sector is directly related to promoting diversity. Cultural entities engage people of different nationalities and views. Art shows that it can connect people despite their differences. That is why many companies undertake philanthropic activities in relation to cultural entities. Supporting diversity and improving the quality of life are directly related to the concept of CSR (Bocquet et al. 2019), as evidenced by the diversity charter under the patronage of the European Commission.

Business support for cultural institutions can be treated as one of the possibilities of implementing the CSR concept. Cultural institutions affect various areas of social life and thus, the values that are important for many social groups. By supporting culture, business may indirectly influence other areas. Culture carries educational heritage and entertainment values that are relevant to society.

The original diagram of the impact business has on culture is presented in Figure 2.

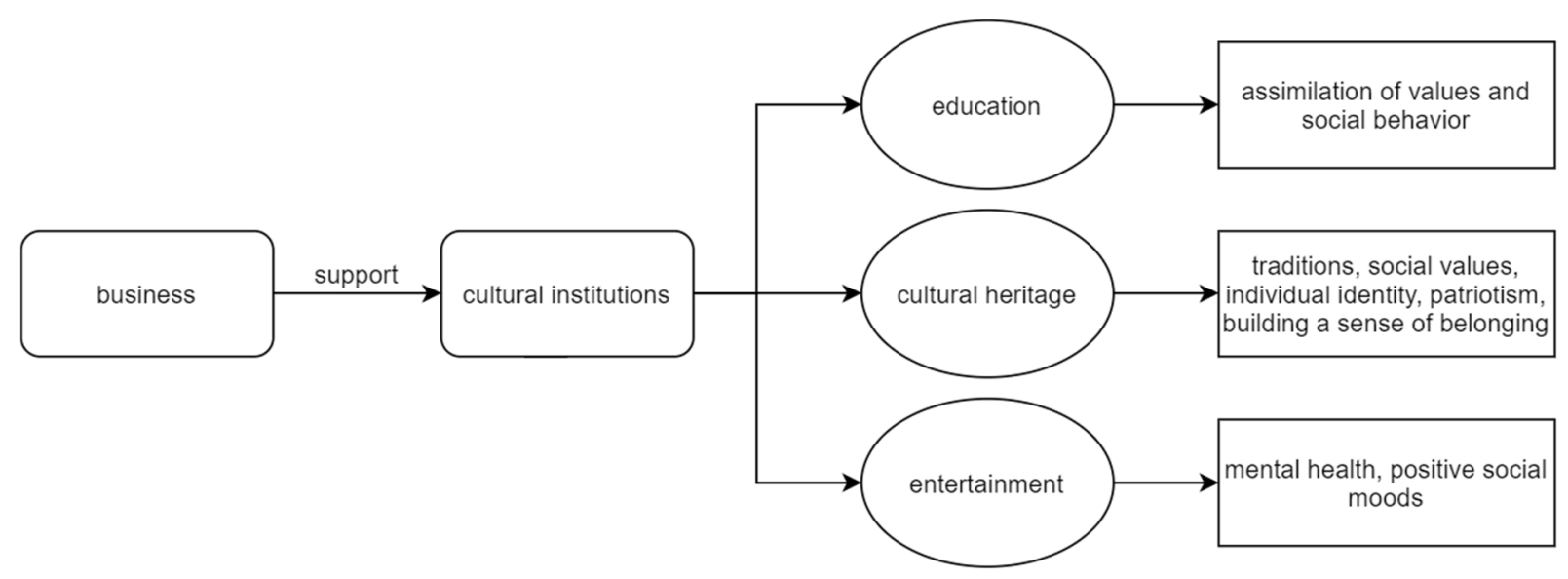

Figure 2. Cultural influence on society. Source: own study.

The first area concerns education (school activities and values flowing from literature and art), the assimilation of values and social behavior. Culture has non-material benefits that contribute to shaping society (Bacq and Eddleston 2018).

The second area involves cultural heritage, the effect of which is to build a sense of belonging, assimilate social values and create the identity of an individual (Nocca 2017). Because of it, a recipient finds their own place in society and assumes a social role. By showing history, traditions are maintained and one may develop deeper patriotism. Therefore, a sense of belonging to a wider community is built.

The third area concerns broadly understood entertainment. By participating in culture, an individual satisfies their need of a higher order and, feeling satisfied, their mood improves. Participation in culture is especially important in times of a pandemic crisis because it also influences positive feelings and thus, mental health (Haas et al. 2021). 
Through culture, business preserves values that are important to society. People find their place and shape these values. Social sensitivity is formed, and because of it, people know what is right and what is wrong (morality). They are more willing to engage in charity and social projects, as well as in corporate volunteering, which is important from the perspective of companies and the goals they pursue (Ocran 2011; Ofori and Hinson 2007). It can be seen that the activities of companies are profitable in the long term, as the results of the activities of sponsored entities create profits (not only material) in the future (Nyarku and Ayekple 2019). Along with increased social awareness and sensitivity, there is a growing willingness to engage in problems important for the local/regional society, as well as on a national and international scale, which is important from the perspective of the CSR concept.

Corporate social responsibility can be seen as a self-regulating model, whereby an organization is accountable to itself, consumers, stakeholders, and society as a whole (Chen 2020). Organizations, wanting to be perceived as socially responsible, decide to act in one or more of the key areas of CSR that are presented in Figure 3.

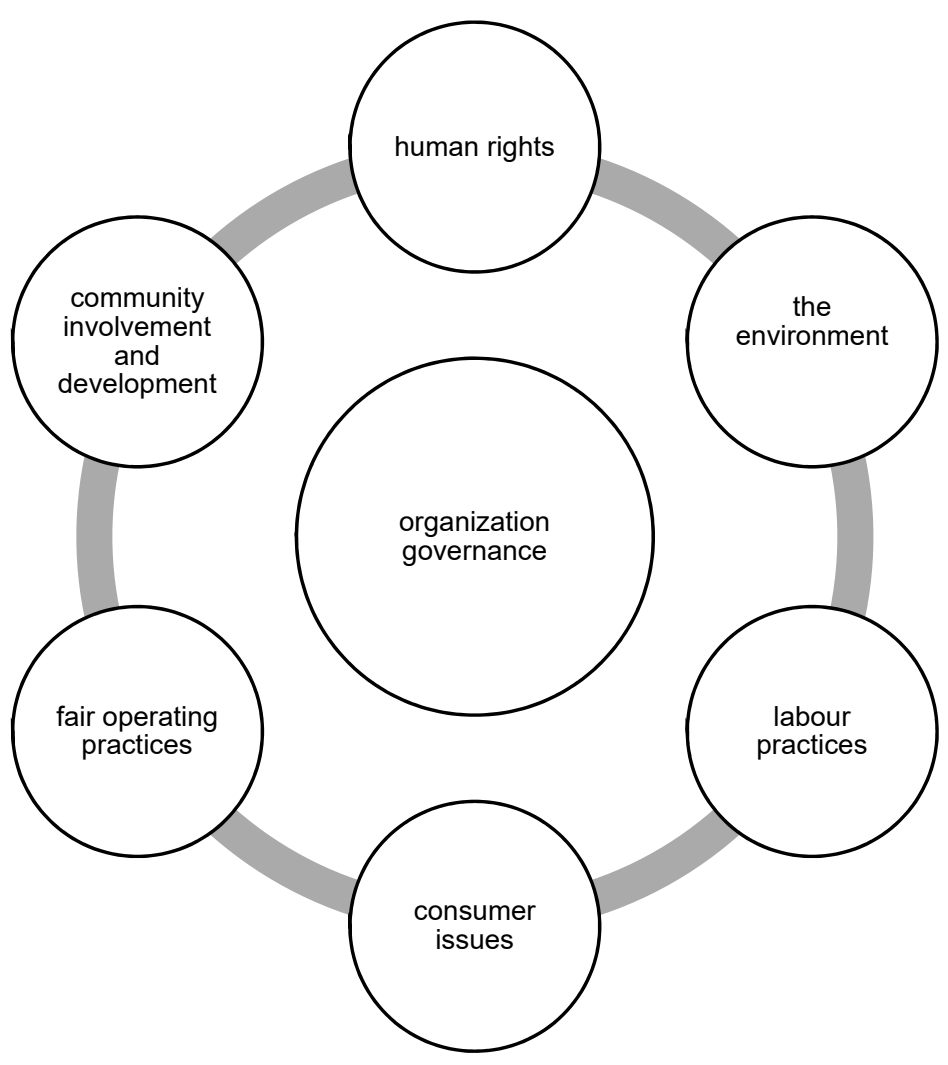

Figure 3. CSR areas according to ISO 26000. Source: own study based on: Polish Standard PN-ISO 26000: 2012 Guidelines on social responsibility in KT 305 for Social Responsibility published on 5 November 2012.

According to the ISO 26000 standard, corporate social responsibility (CSR) should be considered in seven key areas. Organizational governance is based on strategic documents, as well as internal codes. Respecting human rights is primarily about respect and proper treatment in the workplace. Within this scope, companies try to support diversity and prevent discrimination in the workplace. Labor practices should be understood as creating space for a company employees, as well as supporting employees of subcontractors. The areas are interdependent with each other, and activities in each of the areas enable a holistic approach.

As emphasized by many organizations, one of the key areas of CSR is environmental protection (Ratajczak 2013). Companies try to meet the expectations of consumers by 
meeting their social needs (Lee 2017b). This is another area of CSR-social commitment (Lee and Shin 2010). It allows for building a relatively permanent bond between the company and the current and potential customer (Walters and Tacon 2010; Babiak and Kihl 2018). This, in turn, allows for a competitive advantage (Fraj-Andrés et al. 2012). Long-term implementation of the CSR policy does not only build a stable relationship with the environment, but can also be converted into profits in the financial dimension (Sznajder 2013; Su et al. 2017). Consumer issues are about meeting their needs with sustainable development and sustainable consumption. Therefore, the company should be ethical and provide the highest quality standards.

As part of the adopted CSR strategy, companies decide to support cultural institutions. Most often, however, one can meet with financial support in the form of sponsorship, philanthropy and the role of the Patron of Culture. For both parties, it is a positive action that has an impact on improving their image. In this way, companies build a dialogue with their stakeholders and cultural institutions gain funds to operate and implement new projects.

\subsection{The COVID-19 Pandemic Influence on Business Environment and Cultural Activities}

On a global scale, the impact of the pandemic is already visible (Sarkodie and Owusu 2020). Local activities related to culture, recreation and production have deteriorated (Piatkowska 2020). The rapid spread of the coronavirus is a threat not only to people's health but also the environment and economy (Huang et al. 2020). The steady increase in the incidence of the coronavirus is a threat to developing countries (Zaręba 2020). Nevertheless, the introduction of restrictions, cancellation of cultural events with the participation of the public, as well as the suspension of the operation of production plants, may improve air purity and have a positive impact on health issues (Gautam and Trivedi 2020). However, it should be emphasized that the temporary closure of different sectors may result in a rebound in the future. This means high unemployment level (Goolsbee and Syverson 2020), a disfunction of cultural events and a renewed degradation of the natural environment. Decisions the government makes today will have a long-term impact on the future economic development.

Currently, many activities that were implemented in a traditional way have been transferred to the Internet (Barnes 2020). For small and medium-sized companies, this is a chance to survive (Guo et al. 2020). This also applies to cultural institutions which, in order to survive, had to adapt to new conditions (Iwanowski and Szewczyk 2020). The implementation of marketing activities and presence in social media may contribute to the improvement of the image of cultural institutions (Wróblewski 2019). Owing to the implemented strategy and well-thought-out communication, cultural institutions are able to gain new clients and obtain the support of sponsors during the pandemic.

This helped the recipients of cultural initiatives to keep experiencing sensual cognition without risking their health. Moreover, cultural institutions implementing initiatives for local communities include their activities in the concept of corporate social responsibility (Sikora-Chołody 2020).

Companies decide to implement a CSR strategy for a variety of reasons that can be related to short-term benefits, consumer expectations or the good of society (Aguilera et al. 2007). They also see long-term benefits in terms of financial profit and gaining consumer confidence. During the first wave of the coronavirus (COVID-19), the activity of companies in the context of socially responsible initiatives was increased (Manuel and Herron 2020). In order to gain the favor of customers and suppliers, organizations must react quickly to any changes in the environment (He and Harris 2020). However, it is noticeable that, in previous years, CSR focused on supporting the society in situations of natural disasters (van der Vegt et al. 2015; Wang et al. 2016). Society expects companies to engage not only in changes but also problems concerning environment and health, which is why CSR is positively evaluated in the pandemic era (Edelman 2020). Nonetheless, companies must approach initiatives with great caution, as they must take care to protect 
employees and themselves from the temptation to act for their own benefit (Bernstein et al. 2020). In Poland, in the first months of the pandemic, an increase in the number of CSR initiatives can be observed. The state-owned enterprises are leaders in terms of the amount of assistance to stakeholders in the pandemic era (Kubiczek 2020).

\section{Material and Methods}

The study consisted of two stages. During the first stage, the reports of Statistics Poland and information on the activities of cultural institutions were used as sources. The data was sourced from all of the 7 available reports.Then, 37 websites and 50 Facebook profiles were chosen arbitrarily in such a way as to ensure diversity in terms of the type of activities (theaters, museums, etc.). On this basis, the impact of the pandemic on cultural activities was determined and the main areas of activity were identified. The second stage was the extension of the research, conducted through sending a request for individual indepth interviews (IDI) to 23 representatives of cultural institutions in Ślaskie Voivodeship. Such a choice was dictated by the fact that the capital of the voivodeship-Katowice, belongs to the UNESCO network of creative cities (since 2013) and is a key representative of the modern approach to culture in Poland. The 10 representatives who replied come from various cultural institutions-three theatres, two museums, two culture creators, and three other institutions.

Asking representatives had the nature of an expert panel because representatives of cultural institutions were themselves responsible for implementing government restrictions in their units and transferring activities to the virtual world. Due to the pandemic, the conversation was conducted in the form of a telephone or email conversation during which, the following questions were asked:

1. Did you move your activities to the Internet when the central restrictions on the closure of cultural institutions were introduced? If so, how was it implemented (performances, virtual tour, etc.)? When did you implement this form of activity and did you encounter any difficulties in preparing and running a "distance" business?

2. During the total "lockdown", did you undertake any solidarity initiatives for the benefit of the local community (e.g., fundraising, sewing masks, delivering purchases, etc.)? If so, what were they?

3. Have you heard about other, similar initiatives in cultural institutions (especially in Śląskie Voivodeship)? If so, please provide examples.

4. In your opinion, what amount of time must pass after the pandemic ends, in order for the functioning of cultural institutions to return to normal? Or do you think the COVID-19 pandemic has had such a strong impact that it will no longer be possible to return to operating in its pre-outbreak form?

On the basis of the obtained responses, the previously determined impact was evaluated and then the impact of the pandemic in the sector of cultural institutions was assessed by synthesizing the aspects common to the responses.

\section{Results}

At the end of March 2020, the number of entities operating in the field of culture registered in the REGON register was 210.7 thousand (Statistics Poland 2020a). The first wave of the pandemic resulted in their closure as the effect of the national quarantine, introduced on 11 March 2020 (Ordinance of the Ministry of Culture and National Heritage of the Republic of Poland 2020). During the period of lower incidence, cultural institutions resumed their activities, however, they were suspended when any employee of the institution became infected with the coronavirus. The re-closure of cultural institutions was the result of the second wave of the SARS-CoV-2 pandemic and took place, by the government's decision, on 4 November 2020 (Ordinance of the Council of Ministers 2020). The renewed increase in the number of infection cases is a significant limitation in forecasting the effects of the pandemic in the area of cultural institutions. 
Statistics Poland $(2020 a, 2020 b)$ has so far conducted two studies on the impact of the COVID-19 pandemic on entities operating in the field of culture. During the Q1 survey, most cultural institutions (53.7\%) experienced the negative effects of the COVID19 pandemic in their assessment through, inter alia, decrease in revenues from business activities, including as much as $72.5 \%$ of them estimating the scale of the decline in revenues from economic activities at the level below $50.0 \%$. In addition, the decline in revenues from business activities above $90.0 \%$ was indicated by $8.6 \%$ of cultural institutions. In Q2 2020, the percentage of cultural institutions that experienced the negative effects of the COVID-19 pandemic increased to $64.95 \%$. Nonetheless, $59.1 \%$ of the surveyed cultural institutions estimated the scale of the decline in revenues from business activity at a level below $50.0 \%$. Moreover, a decrease in revenues from business activities above $90.0 \%$ was recorded by as much as $13.7 \%$ of institutions (an increase by $37.22 \%$ ). Figure 4 presents cultural institutions that, in their assessment, experienced the negative effects of the COVID-19 pandemic in the second quarter of 2020, broken down by voivodship.

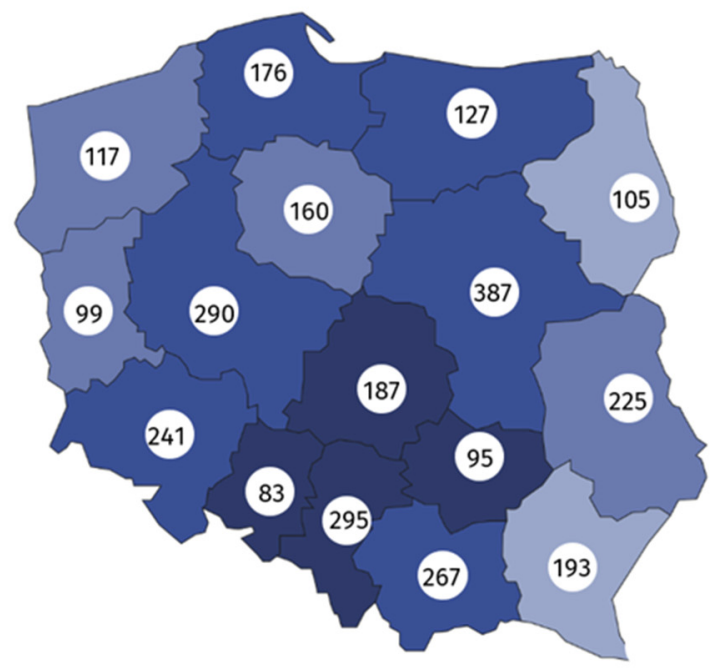

Number of cultural institutions

3047 which, in their assessment, experienced the negative effects of the COVID-19 pandemic

Percentage of cultural institutions estimating the scale of the decrease in revenues at the level above $90 \%$

Figure 4. Cultural institutions which in their assessment experienced the negative effects of the COVID-19 pandemic in the second quarter of 2020. Source: (Statistics Poland 2020b).

In the first half of the year, the total revenue of cultural institutions decreased from PLN 5007.7 to PLN 4,658.1 million (7.0\%) compared to the previous year (Statistics Poland 2020c). Currently, cultural activity is in virtual form as the result of the introduced government restrictions. An example of such activity is the Ars Cameralis festival in Katowice, where one needs to purchase a ticket. Due to the pandemic, the organizers decided to transfer it to the Internet and decided that participation was free. It is worth noting that, in addition to transferring their core activities to the Internet, cultural institutions expanded their offer with additional events. Moreover, they have undertaken initiatives for the benefit of the local community, which can be treated as the implementation of a social responsibility policy. All representatives of cultural institutions with whom the IDI survey was conducted, indicated that at the moment of the closure of their institutions, they began to virtualize their offer. This process took place in stages, and the types of carried out activities varied. The greatest problem was the lack of previous experience in running an online business.

It should be emphasized that restrictions significantly limited not only the activities of the cultural institutions themselves, but also freelance artists. The cancellation of performances or shows resulted in loss of source of income for many people. In the cultural sector, the following entities affected by the coronavirus are identified (GAP Foundation 2020, p. 11):

1. Full-time employees of public institutions;

2. Non-governmental organizations (NGOs);

3. Galleries and other small independent entities; 
4. Business entities, including publishers, organizers of art festivals and events, fairs, art enterprises, and agencies;

5. Working under civil law contracts; and

6. Individuals without any permanent employment, contract and insurance, including health insurance.

There was, therefore, the need to help this particular group of people. The Polish government launched the Culture Support Fund with a budget of PLN 400 million. Its purpose is to provide financial support to local government's art institutions, non-governmental organizations and entrepreneurs conducting cultural activities in the field of theater, music and dance. The assumed effect is to ensure the stable functioning of the institution and to maintain the current employment in the cultural sector. Local self-government units also helped artists. The City of Kraków has launched the "Resilient Culture" project aimed at supporting artists by awarding scholarships for creative and artistic activities.

The City of Katowice has prepared the Katowice Package for Culture which consists of 4 pillars. The first pillar is in the form of financial aid, the budget of which was PLN 500,000. The artists could submit applications for funding activities in three categories: music, theater and general culture. The second pillar concerns organizations operating in the field of culture, especially NGOs, and provides assistance in the form of partial dismissal and deferral of rent. The third pillar provides for exemptions from property tax for NGOs operating in the field of culture. The fourth pillar is to enable the virtualization of projects that received funding from the City of Katowice as part of the tender competition.

\section{Types of Culture Activities in the Pandemic Era}

The type of cultural activity carried out depends on the specificity of the cultural institution. In order to identify similarities in the impact of the COVID-19 pandemic on the activities of institutional culture, the responses of the respondents were collected and compared in Table 1.

Based on the conducted literature studies and the analysis of the activities of cultural institutions in the pandemic era, the following division, according to the form of conducted activity, is proposed:

1. Previous activities in a virtual form.

2. Expanding activities with additional initiatives.

3. Initiatives in the area of CSR.

Initiatives from basic activities in a virtual form were addressed to the current recipients of the offer. It should be noted that some people, especially the elderly, are digitally excluded, which means that they cannot take part in the virtual form of cultural institutions' offer. Moreover, the digital version of culture, due to its form, may not be preferred by the current audience. Therefore, cultural institutions were looking for a new audience that would compensate for the loss of the existing recipients of their offer. The expansion of the activity compensates the lack of the public. Among the most frequently used practices, classes for children and young people who, due to the closure of schools and kindergartens, spent time at home while their parents worked remotely, should be distinguished.

On the other hand, going beyond the standard goal of the activity, which is to provide services in the area of culture, should be treated as an activity within the scope of corporate social responsibility. Culture joined social activities to help others during the pandemic. The study showed that, during the pandemic, the activities of cultural institutions in the field of CSR focus on supporting the local community. Tailors of theaters (including Zagłębie in Sosnowiec, Ślaski in Katowice, Jan Kochanowski in Opole, Aleksander Wegierka in Białystok and Stefan Żeromski in Kielce) joined in sewing masks, while employees of Katowice Miasto Ogrodów joined in delivering purchases to seniors.

Cultural institutions not only initiate activities in the field of social responsibility, but due to the difficult situation they find themselves in, they are beneficiaries of initiatives supporting culture. The Zagłebie Theater sells the donation tickets, other institutions decide to organize crowdfunding collections. It is emphasized that in the era of the pandemic, 
specialized agencies developing individual fields of art and informal cooperatives play an increasingly important role (GAP Foundation 2020).

Table 1. Comparison of the impact of the outbreak of the COVID-19 pandemic on the activities of cultural institutions in Śląskie Voivodeship-IDI results.

\begin{tabular}{ll}
\hline Type of Cultural Institution & \multicolumn{1}{c}{ Activity } \\
\hline & We stopped performing on stage and moved our activities to the Internet. \\
Our activities focused on the transmission of reading fairy tales and books. & Online spectating continues. Now we stream a real-time spectacle. \\
We did not organize any competitions, however, we involed the audience in selecting the & next projects. We used interactivity tools in social media. \\
The had a real-time chat with viewers. & At the beginning, we switched from theater to pro-social. In response to the needs, we \\
& sewed masks. We managed to sew 10,000 of them. \\
& We have created a series of actor performances of fairy tales. In cooperation with the \\
directors, a series of films was created - a record of the first wave of the pandemic. & Padnemic influenced the virtualization of our acitivity.
\end{tabular}

Cinema

Cinema

Museum/Art Gallery

\section{No Reply from the Respondents}

We transferred some of the collections to the Internet and are still in the process of digitizing.

During the first wave, we also took care of our interaction with recipients by recording videos and sharing them on the Internet.

Museums are a specific group of cultural entities because employees do not have such contact with visitors as people do in other cultural entities.

Philharmonic No Reply from the Respondents

The library services were performed remotely by digitizing the collections and making them available through digital libraries (also at the request of users).

A remote account registration service was launched, thanks to which readers could, after registration, use electronic library resources (databases, digital libraries, online magazines,

Libraries repositories);

We have created the possibility of contactless borrowing of publications via book machines. Information on new possibilities of using resources and instructional videos appeared on social media and on the website.

We have also moved some cultural events (e.g., exhibitions) to the online zone.

With the closure of the institution, we immediately began working on redirecting our activities to the network. We started with simple forms-Internet competitions or workshops (mainly for children) recorded by our coordinators with the available equipment (smartphones). After 3 weeks, we were able to offer more technologically advanced projects.

Source: Own elaboration.

The cultural offer was virtualized in stages. The representatives themselves indicate that they started with the implementation of "simple forms-Internet contests or workshops (aimed at children) recorded by our coordinators with the available equipment (telephones)". Libraries have started digitizing their collections and making them available through digital libraries (also at the request of users). An innovative solution was the implementation of the possibility of contactless borrowing of publications via book machines. For users who have not used this form of borrowing books before, libraries have prepared instructional videos. The introduction of book-machines aroused great interest among readers. The process of adaptation of cultural institutions to the pandemic conditions is presented in Figure 5.

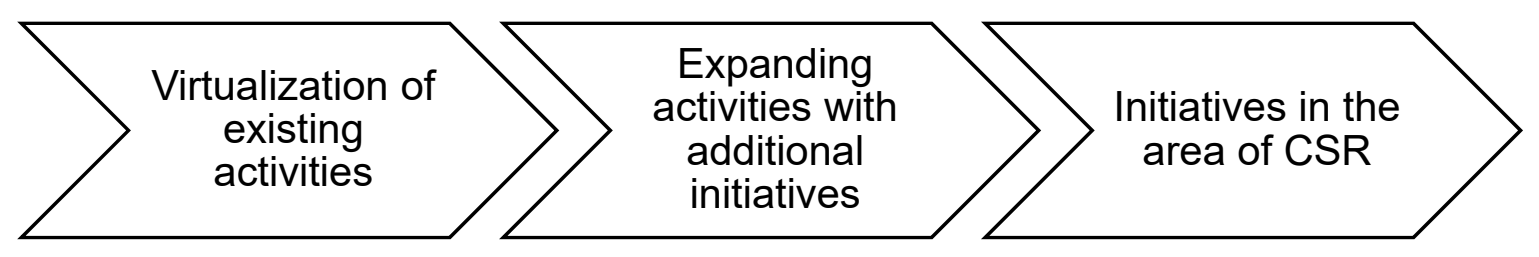

Figure 5. The process of adaptation of cultural institutions to the pandemic conditions. Source: own study. 


\section{Discussion}

Government restrictions imposed on cultural institutions have created a difficult alternative for their managers: ceasing operations or virtualization of the offer. In order to be able to continue to operate, culture was forced to redefine its unchanging approach to the offer. On the one hand, virtualization made it possible to reach new audiences who are limited in mobility or are in a remote location. On the other hand, some of the recipients so far have given up experiencing culture. This has to do with reduced sensations and sensory impressions that depreciate online. It should also be emphasized that not everyone has the opportunity to participate in online culture as they may be digitally excluded.

Based on the conducted research, it can be concluded that competition in culture sector moved to the Internet, forcing the intensification of marketing activities. Factors that may have influenced the decision to choose a cultural institution up to now (such as the location and the time it takes to reach it), do not matter in the virtual world. Cultural institutions focused on their already existing offer, shooting at creating their competitive advantage based on a cultural product. Improvement consists not only of increasing the quality of the offer but also of its diversification. The virtualization of the offer opens up new market segments that so far have not been noticed by culture managers or have been beyond their reach. The virtualization of culture could also be delayed by decision-makers who were used to typical solutions and were afraid to enter the digital world. The pandemic forced the changes that, in the long-term, may contribute to faster technological progress and the development of online services.

A significant number of cultural institutions went beyond their standard activities to be involved in the local community. Due to the difficult financial situation of cultural institutions, their CSR activities involve not only financial resources but also human capital. This is a similarity in the activities of social responsibility conducted by cultural institutions. The most common activities involved sewing masks and supporting seniors by, among others, delivering purchases.

\section{Conclusions}

The conducted study fills the identified research gap. It shows how the cultural sector handles the activity aspect in the pandemic, which was particularly vulnerable to the impact of the coronavirus. Based on the survey, cultural institutions can compare how other members of the sector reacted to the restrictions introduced by the government. From the perspective of the public sector economy, the importance of cultural institutions, as important entities positively influencing the local community, was determined.

The greatest limitation was its national character. Expand the study by including additional entities. This could help to understand the phenomenon on the international arena better. Nevertheless, this study has many practical and theoretical implications. The activities of the analyzed cultural units and the opinions of experts could be a valuable source of knowledge for entities that found themselves in a similar situation.

Author Contributions: Conceptualization: A.K. and J.K.; methodology: J.K.; validation: A.K.; formal analysis: A.K. and J.K.; resources: A.K. and J.K.; data curation: J.K.; writing-original draft preparation: A.K. and J.K.; writing-review and editing: A.K. and J.K.; visualization: A.K.; supervision: J.K.; project administration: J.K. All authors have read and agreed to the published version of the manuscript.

Funding: This research received no external funding.

Institutional Review Board Statement: Not applicable.

Informed Consent Statement: Not applicable.

Acknowledgments: We would like to express our sincere appreciation to Aleksandra Burgiel with whom we consulted the methods used in the paper. We would also like to thank Karolina Bolanowska for her language suggestions and diligent proofreading of this paper.

Conflicts of Interest: The authors declare no conflict of interest. 


\section{References}

Abisuga Oyekunle, Oluwayemisi Adebola, and Mziwoxolo Sirayi. 2018. The role of creative industries as a driver for a sustainable economy: A case of South Africa. Creative Industries Journal 11: 225-44. [CrossRef]

Aguilera, Ruth, Deborah Rupp, Cynthia Williams, and Jyoti Ganapathi. 2007. Putting the S back in corporate social responsibility: A multilevel theory of social change in organizations. Academy of Management Review 32: 836-63. [CrossRef]

Babiak, Kathy, and Lisa A. Kihl. 2018. A case study of stakeholder dialogue in professional sport: An example of CSR engagement. Business and Society Review 123: 119-49. [CrossRef]

Bacq, Sophie, and Kimberly A. Eddleston. 2018. A Resource-Based View of Social Entrepreneurship: How Stewardship Culture Benefits Scale of Social Impact. Journal of Business Ethics 152: 589-611. [CrossRef]

Bailey Christopher, Steven Miles, and Peter Stark. 2004. Culture-led urban regeneration and the revitalisation of identities in Newcastle, Gateshead and the North East of England. International Journal of Cultural Policy 10: 47-65. [CrossRef]

Barnes, Stuart J. 2020. Information management research and practice in the post-COVID-19 world. International Journal of Information Management 55: 102175. [CrossRef]

Bernstein, Justin, Brian Hutler, Travis Rieder, Ruth Faden, Hahrie Han, and Anne Barnhill. 2020. An Ethics Framework for the COVID-19 Reopening Process. Working Paper, Johns Hopkins University of Medicine, Baltimore, MD, USA. Available online: https:/ / bioethics.jhu.edu/wp-content/uploads/2019/10/FINAL-SNF-Agora-Covid-19.pdf (accessed on 20 November 2020).

Bocquet, Rachel, Christian Le Bas, Caroline Mothe, and Nicolas Poussing. 2019. Strategic CSR for innovation in SMEs: Does diversity matter? Long Range Planning 52: 101913. [CrossRef]

Cacioppo, John T., and Louise C. Hawkley. 2009. Perceived social isolation and cognition. Trends in Cognitive Sciences 13: 447-54. [CrossRef]

Campbell, Angus, Philip E. Converse, and Willard L. Rogers. 1976. The Quality of American Life: Perceptions, Evaluations and Satisfactions. New York: Russell Sage Foundation.

Caves, Richard E. 2000. Creative Industries: Contracts between Art and Commerce (No. 20). Cambridge: Harvard University Press.

Chen, Jason. 2020. What Is Corporate Social Responsibility (CSR)? Investopedia. Available online: www.investopedia.com/terms/c/ corp-social-responsibility.asp (accessed on 20 November 2020).

DCMS. 2011. Annual Report and Accounts 2011-12. London: Department for Digital, Culture, Media \& Sport.

Donthu, Naveen, and Andres Gustafsson. 2020. Effects of COVID-19 on business and research. Elsevier Public Health Emergency Collection 117: 284-89. [CrossRef]

Edelman. 2020. Edelman Trust Barometer Special Report on COVID-19 Demonstrates Essential Role of the Private Sector. Available online: www.edelman.com/research/edelman-trust-covid-19-demonstrates-essential-role-of-private-sector (accessed on 20 November 2020).

Fraj-Andrés, Elena, M. Eugenia López-Pérez, Iguácel Melero-Polo, and Rosario Vázquez-Carrasco. 2012. Company image and corporate social responsibility: Reflecting with SMEs' managers. Journal of Marketing Intelligence E Planning 30: 266-80. [CrossRef]

Gaanguly Anirban, Aasim Talukdar, and Debdeep Chatterjee. 2019. Evaluating the role of social capital, tacit knowledge sharing, knowledge quality and reciprocity in determining innovation capability of an organization. Journal of Knowledge Management 23: 1106-1135. [CrossRef]

GAP Foundation. 2020. Raport kultura. Pierwsza do zamknięcia, ostatnia do otwarcia. Kultura w czasie pandemii COVID-19. Kraków: GAP Foundation.

Gardocka, Anna. 2005. Kultura ekonomiczna jako instytucja. In Teoretyczne Aspekty Gospodarowania. Edited by Kopycińska Danuta. Szczecin: Wydawnictwo Uniwersytetu Szczecińskiego, pp. 229-39.

Gautam, Sneha, and Ujwalkumar Trivedi. 2020. Global implications of bio-aerosol in pandemic. Environment, Development and Sustainability 22: 3861-65. [CrossRef]

Geertz, Clifford. 2003. Wędrówka i przypadek: Żywot uczonego. In Zastane światło. Antropologiczne refleksje na tematy filozoficzne (tł. Z. Pucek). Kraków: Towarzystwo Autorów i Wydawców Prac Naukowych Universitas, pp. 11-32.

Goolsbee, Austan, and Chad Syverson. 2020. Fear, Lockdown, and Diversion: Comparing Drivers of Pandemic Economic Decline 2020. National Bureau of Economic Research. [CrossRef]

Grabowska-Pieśla, Anna. 2013. Wielowymiarowa rola kultury w rozwoju gospodarczym regionów. Zeszyty Naukowe Uniwersytetu Szczecińskiego. Ekonomiczne Problemy Ustug 103: 53-63.

Guo, Hai, Zhuen Yang, Ran Huang, and Anqi Guo. 2020. The digitalization and public crisis responses of small and medium enterprises: Implications from a COVID-19 survey. Frontiers of Business Research in China 14. [CrossRef]

Haas, Brian W., Fumiko Hoeft, and Kazufumi Omura. 2021. The role of culture on the link between worldviews on nature and psychological health during the COVID-19 pandemic. Personality and Individual Differences 170: 110336. [CrossRef]

He, Hongwei, and Lloyd Harris. 2020. The impact of Covid-19 pandemic on corporate social responsibility and marketing philosophy. Journal of Business Research 116: 176-82. [CrossRef]

Huang, Chaolin, Yeming Wang, Xingwang Li, Lili Ren, Jianping Zhao, Yi Hu, Li Zhang, Guohui Fan, Jiuyang Xu, Xiaoying Gu, and et al. 2020. Clinical features of patients infected with 2019 novel coronavirus in Wuhan, China. The Lancet 395: 497-506. [CrossRef]

ISO 26000. 2012. Wytyczne dotyczace społecznej odpowiedzialności w KT 305 ds. Społecznej odpowiedzialności. Warszawa: Polski Komitet Normalizacyjny. 
Iwanowski, Damian, and Nikodem Szewczyk. 2020. Inna kultura jest możliwa. Koronawirus i przyszłość kultury w Polsce. Instrat Policy Paper 2020: 5.

Kantor, Angelika, and Jakub Kubiczek. 2020. Działalność biznesu na rzecz kultury w kontekście koncepcji CSR. In Biznes w KulturzeKultura w Biznesie w Koncepcji Zrównoważonego Rozwoju. Edited by Reformat Beata and Kwiecień Anna. Katowice: Wydawnictwo Uniwersytetu Ekonomicznego w Katowicach, pp. 41-52.

Klasik, Andrzej. 2010. Sektor kultury i przemysły kreatywne nowym fundamentem rozwoju dużych miast i aglomeracji miejskich. In Rola Sektora Kultury i Przemystów Kreatywnych w Rozwoju Miast i Aglomeracji. Edited by Spadzińska-Żak Elżbieta. Katowice: Wydawnictwo Uniwersytetu Ekonomicznego, pp. 11-39.

Kostro, Krzysztof. 2009. Zagadnienia kulturowe w ekonomii. Gospodarka Narodowa 3: 27-59. [CrossRef]

Kowalczyk, Anna Zofia. 2012. Kulturowe uwarunkowania gospodarki i rozwoju gospodarczego. Rynek—Społeczeństwo-Kultura 2: $5-13$.

Kroeber, Afred Louis. 1987. Istota Kultury. Warszawa: PWN.

Kubicka, Joanna. 2016. Stan wdrożenia zmian w zarządzaniu organizacjami z sektora kultury i sektorów kreatywnych wynikających ze zmian w otoczeniu. Roczniki Kulturoznawcze VII: 133-45.

Kubiczek, Jakub. 2020. Corporate Social Responsibility in the era of the SARS-CoV-2 pandemic-Experiences from Poland. forthcoming.

Kwiecień, Anna. 2020. Rola kultury w rozwoju społeczno-gospodarczym. In Biznes w Kulturze—Kultura w Biznesie w Koncepcji Zrównoważonego Rozwoju. Edited by Reformat Beata and Kwiecień Anna. Katowice: Wydawnictwo Uniwersytetu Ekonomicznego w Katowicach, pp. 9-16.

Lee, Hye-Kyung. 2017a. The political economy of 'creative industries' Media. Culture E Society 39: 1078-88. [CrossRef]

Lee, Ki-Hoon, and Dongyoung Shin. 2010. Consumers' responses to CSR activities. The linkage between increased awareness and purchase intention. Public Relations Review 36: 193-95. [CrossRef]

Lee, Yoon-Joo. 2017b. How Do Self-Values Play a Role in Consumers' Perception of CSR Advertising? Journal of Advertising Research 57: 422-35. [CrossRef]

Manuel, Timothy, and Terri Herron. 2020. An ethical perspective of business CSR and the COVID-19 pandemic. Society and Business Review 15: 235-36. [CrossRef]

McKibbin, Warwick, and Roshen Fernando. 2020. The economic impact of Covid-19. In Economics in the Time of COVID-19. Edited by Baldwin Richard and di Mauro Beatrice Weder. London: CEPR Press, pp. 45-53.

Nguyen, Hoang C., Minh H. Nguyen, Binh N. Do, Cuong Q. Tran, Thao T. P. Nguyen, Khue M. Pham, Linh V. Pham, Khanh V. Tran, Trang T. Duong, Tien V. Tran, and et al. 2020. People with Suspected COVID-19 Symptoms Were More Likely Depressed and Had Lower Health-Related Quality of Life: The Potential Benefit of Health Literacy. Journal of Clinical Medicine 9: 965. [CrossRef] [PubMed]

Nocca, Francesca. 2017. The Role of Cultural Heritage in Sustainable Development: Multidimensional Indicators as Decision-Making Tool. Sustainability 9: 1882. [CrossRef]

Nyarku, Kwamena, and Seth Ayekple. 2019. Influence of corporate social responsibility on non-financial performance. Social Responsibility Journal 15. [CrossRef]

Ocran, Emmanuel. 2011. The Effect of Corporate Social Responsibility (CSR) on Profitability of Multinational Companies: A Case Study of Nestle Ghana Limited. Doctoral dissertation, Institute of Distance Learning, Kwame Nkrumah University of Science and Technology, Ashanti, Ghana.

Ofori, Dan, and Robert Hinson. 2007. CSR perspectives of leading firms in Ghana, Corporate Governance. The International Journal of Business in Society 7: 178-93. [CrossRef]

Ordinance of the Council of Ministers. 2020. Amending the Regulation on the Establishment of Certain Restrictions, Orders and Bans in Connection with the Occurrence of an Epidemic. Journal of Laws 2020, item 1972. November 6.

Ordinance of the Ministry of Culture and National Heritage of the Republic of Poland. 2020. On the temporary limitation of the functioning of education system units in connection with the prevention, counteraction and combating COVID-19. Journal of Laws 2020, item 403. March 11.

Park, YeJin, Youngwon Park, Paul Hong, and Soye Yang. 2017. Clarity of CSR orientation and firm performance: Case of Japanese SMEs. Benchmarking: An International Journal 24: 1581-96. [CrossRef]

Piątkowska, Marzena. 2020. Analiza wybranych aspektów dotyczących roli pracy w życiu człowieka w okresie pandemii koronawirusa w Polsce w kontekście zdrowia publicznego. In Korpus Humanitarny. Warszawa: Ministerstwo Edukacji i Nauki, Narodowy Uniwersytet Pedagogiczny, p. 2.

Ratajczak, Marcin. 2013. Ekorozwój jako podstawa odpowiedzialnego biznesu (CSR) w obszarze środowiska naturalnego. Prace Naukowe Uniwersytetu Ekonomicznego we Wroctawiu 288: 151-59.

Sarkodie, Samuel Asumadu, and Phebe Asantewaa Owusu. 2020. Global assessment of environment, health and economic impact of the novel coronavirus (COVID-19). Environment, Development and Sustainability. [CrossRef] [PubMed]

Sikora-Chołody, Ewa. 2020. Społeczna odpowiedzialność biznesu w dobie kryzysu gospodarczego. In Interdyscyplinarne elementy nauk społecznych. Zarzadzanie-Ekonomia-Urbanistyka-Zdrowie. Edited by Nosorowski Dariusz and Borcuch Artur. Kielce: Wydawnictwo Laboratorium Wiedzy Artur Borcuch, pp. 99-108.

Spanulescu, Ion, and Anca Gheorghiu. 2020. The impact of coronavirus COVID-19 on world economy-An econophsics approach and model. Hyperion International Journal of Econophysics \& New Economy 13: 7-19. 
Środa-Murawska, Stefania, and Daniela Szymańska. 2013. Przemysł kultury w rozwoju miast. Wybrane aspekty. Zeszyty Naukowe Uniwersytetu Szczecińskiego. Ekonomiczne Problemy Ustug 107: 85-98.

Statistics Poland. 2020a. Wptyw pandemii COVID-19 na podmioty działajace w obszarze kultury w I kwartale 2020 r; Warszawa: Statistics Poland.

Statistics Poland. 2020b. Wptyw pandemii COVID-19 na podmioty działajace w obszarze kultury w II kwartale 2020 r; Warszawa: Statistics Poland.

Statistics Poland. 2020c. Wyniki finansowe instytucji kultury w okresie I-VI 2020 r; Warszawa: Statistics Poland.

$\mathrm{Su}$, Lukun, Liang Wang, Rob Law, Xiaohong Chen, and Davis Fong. 2017. Influences of destination social responsibility on the relationship quality with residents and destination economic performance. Journal of Travel and Tourism Marketing 34: 488-502. [CrossRef]

Sznajder, Marta. 2013. Korzyści z wdrożenia koncepcji społecznej odpowiedzialności biznesu (z uwzględnieniem koncepcji interesariuszy). Ekonomia i Zarzadzanie 5: 194-211. [CrossRef]

van der Vegt, Gerben, Peter Essens, Margaretha Wahlström, and Gerard George. 2015. From the editors: Managing risk and resilience. Academy of Management Journal 58: 971-80. [CrossRef]

Walters, Geoff, and Richard Tacon. 2010. Corporate social responsibility in sport: Stakeholder management in the UK football industry. Journal of Management E Organization 16: 566-86. [CrossRef]

Wang, Heli, Li Tong, Riki Takeuchi, and Gerard George. 2016. Corporate Social Responsibility: An Overview and New Research Directions. Academy of Management Journal, Academy of Management 59: 534-44. [CrossRef]

Weber, Max. 1994. Etyka Protestancka a duch Kapitalizmu. Lublin: Wydawnictwo TEST.

White, Pauline. 2010. Creative industries in a rural region: Creative West: The creative sector in the Western Region of Ireland. Creative Industries Journal 3: 79-88. [CrossRef]

Wilkin, Jerzy. 2016. Kultura a Gospodarka, Sprawy Nauki, 27 Listopada. Available online: http://www.sprawynauki.edu.pl/ archiwum/dzialy-wyd-elektron/312-ekonomia-el3/3472-kultura-a-gospodarka (accessed on 20 November 2020).

Włodarczyk, Ewa. 2003. Kultura. In Encyklopedia Pedagogiczna XXI Wieku. Edited by Pilch Tadeusz. Warszawa: Wydawnictwo Naukowe Żak, vol. 2.

Wnukowski, Damian. 2020. Konsekwencje epidemii koronawirusa dla gospodarki Unii Europejskiej. Polski Instytut Spraw Międzynarodowych 45. Available online: https://pism.pl/publikacje/Konsekwencje_epidemii_koronawirusa_dla_gospodarki_UE (accessed on 20 November 2020).

Wróblewski, Łukasz. 2019. Rola i znaczenie aktywności online użytkowników mediów społecznościowych w kształtowaniu wizerunku instytucji kultury. Zarzadzanie w Kulturze, Uniwersytet Jagiellonski-Wydawnictwo Uniwersytetu Jagiellonskiego 20: 221-39. [CrossRef]

Żak, Katarzyna. 2020. Koncepcja zrównoważonego rozwoju w jednostkach organizacyjnych sektora kultury. In Biznes w KulturzeKultura w Biznesie w Koncepcji Zrównoważonego Rozwoju. Edited by Reformat Beata and Kwiecień Anna. Katowice: Wydawnictwo Uniwersytetu Ekonomicznego w Katowicach, pp. 17-29.

Zaręba, Szymon. 2020. WHO i COVID-19—Spóźniony Start i Nadrabianie Zaległości, Polski Instytut Spraw Międzynarodowych. Available online: https://www.pism.pl/publikacje/WHO_i_COVID19_spozniony_start_i_nadrabianie_zaleglosci (accessed on 20 November 2020).

Zwanka, Russell, and Cheryl Buff. 2020. COVID-19 Generation: A Conceptual Framework of the Consumer Behavioral Shifts to Be Caused by the COVID-19 Pandemic. Journal of International Consumer Marketing 33. [CrossRef] 